\title{
PIONEER
}

VOLUME 13, Issue 2, December 2021: 162 - 172

\section{THE WASHBACK EFFECT IN ONLINE LANGUAGE ASSESSMENT ON STUDENT'S LEARNING INTEREST}

\author{
${ }^{1}$ Amalul Umam \\ ${ }^{1}$ Ibn Khaldun University, Indonesia \\ Iamalul.umam@uika-bogor.ac.id \\ ${ }^{2}$ Olivia Widad Zabidi* \\ ${ }^{2}$ Ibn Khaldun University, Indonesia \\ ²oliviazabidi@gmail.com
}
*Corresponding author: oliviazabidi@gmail.com
Received : October 9, $2021 \quad$ Revised : December 21, 2021
Accepted : December 25, $2021 \quad$ Published : December 31, 2021

\begin{abstract}
This research was conducted with a descriptive-qualitative approach with a case study as the research design. Data was collected by conducting interviews via Google Form with openended questions, the number of students who were used as respondents was 30 students from the Department of English Education. This study aims to examine the assessment process in the summary of assignments for the Seminar Proposal course for the English Education Department. This rapidly growing world of technology also affects aspects of education, education can be run online without the need for face-to-face meetings. Especially at this time where the world is being hit by the Covid-19 virus which increasingly requires people to stay at home. Learning is done entirely at home by relying on online learning. Even so, teachers still need to pay attention to choosing the right assessment for students in order to produce a positive washback effect from each given task. The results of this study indicate that the assignment has a positive washback effect because it is considered capable of improving students' English skills and abilities.
\end{abstract}

Keywords: English learning, language assessment, online learning, washback effects

\section{INTRODUCTION}

The increasingly rapid development of the era certainly brings various positive and negative impacts. The Covid-19 pandemic has an impact on many sectors, including health, economy, and education (Saputri et al., 2020). It is able to create a sense of the need for a learning mechanism that is also based on information technology so as not to seem out of date. The concept of learning, known as e-learning, has the impact of changing or transforming education from conventional forms into digital forms, both in terms of content and systems. The use of e-learning facilities is increasingly becoming a 
necessity in the world of education, especially in higher education. Technology-based learning has been increasingly used since the Covid-19 Pandemic which was a heartbreaking disaster for the entire population of the earth. All human life on earth is disturbed, without exception education. Many countries have decided to close schools, colleges and universities, including Indonesia (Syah, 2020).

At first, the spread of the corona virus had a huge impact on the world's economy, which was starting to sluggish, and it is now also having an impact on the world of education. Policies that have been taken by many countries including Indonesia are also by canceling all educational activities, and making the government and related institutions have to present alternatives for the educational process for students who are currently unable to carry out the learning process or educational process at an educational institution (Dewi, 2020). With the Covid-19 virus, the learning process has changed from face-to-face learning to online-based learning. According to Yunita (2020) in Indonesia, distance or online learning begins on March 16, 2020, where students start learning from their own homes without the need to go to school.

Talking about online learning, it is important for the teachers to master the technology they can run the online learning effectively even during the pandemic. The consequence of physically closing educational institutions and replacing them with learning from home as per government policy is a change in the teaching and learning system. School managers, students, parents, and of course teachers must migrate to digital or online learning system, which is better known as e-learning. Learning must continue, even though there is a global pandemic disaster that makes the government implement social distancing in the world. The most appropriate solution during this pandemic is online learning. Online learning is basically learning that is done virtually through available virtual applications. However, online learning must still pay attention to the competencies to be taught. Online learning is not just material that is transferred through internet media, it is also not just assignments and questions sent through social media applications.

Online learning must be planned, implemented, and evaluated as well as learning that occurs in the classroom. In connection with this, teachers are required to be more innovative in learning activities. Teachers must have their own assessment method in order to measure students' abilities and skills in understanding the material itself. In the 
teaching process, the material must be adapted to the needs of students and designed in an attractive way then implemented based on the latest properties curriculum, interesting teaching materials can be found in authentic teaching materials (Jaelani, 2021). Class assessment is basically a series of educator activities related to making decisions about the achievement of competencies or learning outcomes of students during the learning process.

The application of assessment is an important part of a learning process related to the achievement of student learning outcomes. Improving the quality of learning requires efforts to optimize the process and overall learning outcomes because the nature of the quality of learning is the quality of the implementation of previously designed programs (Uno, 2017). This is also reinforced by the form of the test used. Currently many assessment methods are inconsistent with what educators and researchers believe can be successful in improving students' learning and understanding. An appropriate assessment is considered to be an effort to integrate learning outcomes measurement activities with the entire learning process. To overcome this problem, several techniques and strategies for determining assessment are needed so that they can suit the needs of students. On the basis of this background, the researcher then conducted a research to determine the appropriate assessment method in determining language assessment. Not only that, the researcher is also interested in examining the washback effects on students resulting from the assessment process chosen by the teacher.

Research related to language assessment in online learning that affects students' interest in learning has been carried out by several researchers, including a research written by Lorna R. Kearns (2012) and Effendy Gultom (2016). The results of the research conducted by Kearns (2012) entitled "Student Assessment in Online Learning: Challenges and Effective Practices" reveals that to advance student learning, teachers must collect data as evidence to inform assessments and provide feedback to students based on assessments. It was also found that story solving technique had improved students' speaking skills. Likewise in the research written by Gultom (2016) entitled "Assessment and Evaluating in EFL Teaching and Learning" which states that the assessment of the English learning process can be carried out in every class session. In assessing English learning outcomes, English teachers must know whether students' competences improve through the English learning process. 


\section{REVIEW OF LITERATURE}

Washback is a term for the impact that occurs after the test is held, both in the teaching and learning process. The washback effect can be positive or negative, depending on the quality of the test. For example, said by Hakim \& Saputra (2020) in a positive washback, what is taught and written in the curriculum will be the same as teaching on certain tests. On the other hand, negative washback occurs in situations where there may be a mismatch of stated teaching objectives and focus, thus leading to abandonment of instructional objectives in favor of exam preparation. In development and assessment plans to meet individual students, teachers are helped if teachers know the level of language proficiency of second language learners, teachers need to know students' strengths and weaknesses in order to plan instruction well (Umam, 2017). As stated by Donzelli (2003), that must support the learning process.

Assessments are all methods used to collect information about students' knowledge, abilities, understanding, attitudes, and motivations which can be done through tests and self-assessments, both formally and informally (Nuriyah, 2014). Assessments are used as a stage to test the results of the learning process. When the assessment function has shifted from the stage of testing the results of the learning process, a washback effect appears. Therefore, the role of washback is needed to predict and ensure that the test has the right influence on teaching and learning in classroom decisions or in the education system in general. Aldawood (2016) said that because washback plays an important role in teaching and learning, parties involved in the teaching and learning process need to understand the concept of washback as a common educational unit, and how this concept can be manipulated positively. Washback is a study that aims to connect teachers and students to high-risk investigations. This phenomenon is used for the benefit of the learning process.

\section{METHOD}

This research is a qualitative research method that aims to examine the assessment process in the Seminar Proposal course where English Language Education students are required to make a summary at each meeting. The researcher chose to use a case study research design in conducting this research. Qualitative research focuses on individual or group problems that are relevant to the problem. The emphasis of this study is to explore 
the assessment process on assignments, as well as to find out whether going through assignments will provide positive or negative washback. To analyze the problem, this article uses a descriptive-qualitative approach. Because this study used a qualitative approach, observations and interviews were used as instruments to collect the data.

The data were collected by conducting interviews via Google Form with openended questions. There were 30 students as the respondents. The results of the interviews were then collected and analyzed. The questions in the interviews were conveyed through three main aspects, namely students' responses regarding the positive and negative impacts of giving assignments, students' difficulties in doing assignments, the effectiveness of the methods used, and responses about whether the application of the task was liked. or not by the students. The questions asked to the respondents were as follows:

1) In your opinion, what are the positive and negative impacts of the Summary assignment at each meeting in the Thesis Proposal Seminar course?

2) During the task, did you often experience difficulties?

3) What are the difficulties did you experience while doing the task?

4) Do you think the assignment is effective and efficient enough to assess students' understanding of the learning materials?

5) With this assignment, it requires you to recall the material discussed. Can this make you feel interested in learning and understanding more deeply about the material being discussed?

6) Do you like the method of assessing through Summary tasks in each meeting?

These questions are intended to explore in-depth information regarding the individual's loyal feelings and opinions towards the Summary task in the Seminar Proposal course.

\section{FINDINGS AND DISCUSSION}

\section{Findings}

The result of this research shows that most of the respondents did not object to online-based learning tasks, because basically, the tasks were still reasonable to be carried 
out every week. This statement was also followed by their opinion regarding the assessment process through assignments. The respondents considered that this assignment had an indirect positive impact on the development of students' abilities because the task could make students understand the material, and of course, they could train their thinking and remembering skills. This was because they were required to review the material discussed and also the material presented. As explained earlier, this task also trained students' critical thinking and translation skills. As the task was carried out online, the students had more time to understand the material intensely outside of class hours.

Behind these positive things, there are also negative things felt by a small number of respondents, particularly those who were dishonest. Because the lecturers did not evaluate and provide further responses regarding the assignments given, the students were often dishonest in doing these assignments. There were indications that some students only copied their friends' summaries, copied the material from the PowerPoint and translated it using Google translate. In addition, from the interviews, it was also found that several respondents often experienced difficulties in carrying out these tasks. Based on the responses of the respondents to the questions that the researchers asked in the interviews, it is known that most of the respondents experienced difficulties or obstacles in doing the task. According to the respondents, they have difficulty regarding their understanding which can be said to be a little lacking. This could be because during the learning process, some respondents did not focus nor pay attention to the material itself.

In addition, there are still many students who submitted the task late. In connection with the results of the interviews above, the researchers were interested in asking questions about their interest in the summary of the task itself. The result showed that most of the respondents were interested in this task because they considered this task to be effective and efficient enough to assess students' understanding of the learning material. Through the assignments given at each of these meetings, the teacher could see to what extent the students understood the material that has been studied. In addition, the existence of this summary assignment was also a measure of how much attention students paid for the course. In the process of making summaries, students had to read or listen to the material again to be able to rewrite it in a language that is easier for themselves to understand. 
Even so, there were still a small number of respondents who were not interested in the task. The reason was, according to a small number of them, because this summary task was considered less effective in the assessment process. These students thought that the assignments given at each meeting often burdened themselves students, as they has other assignments from other courses. The researcher asked the students some questions about the summary of assignments that required the students to recall the material that has been discussed, and whether this could make the students provoked to learn and understand more deeply about the material discussed. The results showed that most of the respondents were used to re-learning and digging deeper into the summaries they wrote. While the rest only did the assignments as a condition of grades or formalities, they were not used to exploring deeper. A detailed discussion of the above findings will be described in the section below.

\section{Discussion}

Based on the data collected by means of a survey and questionnaires, it is known that the summary task in the proposal seminar course was considered effective and quite efficient in the language assessment process. This was because most students felt interested in doing this task. Besides, this task had a positive impact on the development of students' language skills. The selection of the type of task was also very influential on the assessment process which was the main element in the learning process. Learning assessment is a process to obtain information in any form that can be used as a basis for making decisions about students both regarding the curriculum, learning programs, school climate and school policies (Poerwanti, 2015). The assignment given to students, of course has a washback, both positively and negatively. Negative washback produced undesirable or uncomfortable effects on teaching and learning for certain tests, which resulted in poor tests and assessed areas that teachers or students did not want to cover. It could also be indicated as a mismatch between the learning content and the test itself. On the other hand, the positive washback refers to the ability of test procedures to encourage good teaching practices. This task could also train students' long-term memory. This longterm memory is involved when processing generate ideas aimed at getting back information that is relevant to the topic to be discussed written. Once the author's memory contains structured information, an idea is organized so that the structure of ideas is more 
valuable (Wahyuni \& Inayati, 2020). The following will explain the advantages and disadvantages of summary assignments in seminar proposal courses based on the responses of the students concerned:

Table 1. Strengths

\begin{tabular}{clll}
\hline No & Strengths & & \\
\hline 1 & Train students' memory skills & 5 & Make students focus on learning \\
2 & Train students' discipline & 6 & Train students' responsibility \\
3 & $\begin{array}{l}\text { Train students' translating and } \\
\text { interpreting skills }\end{array}$ & 7 & $\begin{array}{l}\text { Train students' time } \\
\text { management skills }\end{array}$ \\
& $\begin{array}{l}\text { Keep making the learning } \\
\text { processs run effectively and have } \\
\text { positive activities even though it's } \\
\text { online-baseed }\end{array}$ & \\
\hline
\end{tabular}

Table 2. Weaknesses

\begin{tabular}{|c|c|c|c|}
\hline No & Weaknesses & & \\
\hline 1 & Not well monitored & 3 & $\begin{array}{l}\text { Allow students to copy the work } \\
\text { of their friends }\end{array}$ \\
\hline 2 & $\begin{array}{l}\text { Allow students to translate with } \\
\text { automatic translator machines } \\
\text { such as google transalte }\end{array}$ & & \\
\hline
\end{tabular}

Based on the findings, it can be seen that there are more advantages compared to the disadvantages of summary assignments in the proposal seminar course. This is in line with the responses and perspectives of the students concerned. With this task, the researcher believes that the summary task in the proposal seminar course can form three basic student abilities, including:

\section{Students' Memory Ability}

This task required the students to remember every material explained by the lecturer and friends who are presenting. Even though there was material in PowerPoint that can be reread, students still had to write and make summaries in their own language. Therefore, it is very important for students to always focus and try to remember the material explained at each meeting.

2. Student's Translating and Interpreting Ability 
The students could also be more and more trained to translate a word and sentence. This was due to the presentation and explanation given by the teacher or lecturer in the class using Indonesian, while the summary was required to be written in English. This assignment was given once a week which means that students would become accustomed to translating. This will have a good impact in the future for the development of students' English skills and abilities.

\section{Train Student's Discipline and Responsibility}

According to some students, they felt that this task was a bit burdensome because it was held at every meeting and had to be done with full concentration. However, for researchers, therein lies the assessment set by the supporting lecturer. This task indirectly required the students to be disciplined and able to manage time well so that all assignments could be completed. This task also trained students' responsibility attitude. Although the lecturer could not fully monitor this task because the learning was done online, the students' attitude of responsibility for himself is very much needed.

\section{CONCLUSIONS AND SUGGESTIONS}

\section{Conclusions}

Learning that must take place online because the world is being hit by the Covid19 virus does not mean that the quality of education must decline. Teachers are required to be able to overcome the problems encountered during the online learning process. The selection of assignments for the assessment process for each student must also be appropriate. The right assessment process will certainly have a positive washback effect as well. The task of making a summary at each meeting in the seminar proposal course is considered quite effective and efficient to improve students' language skills and abilities. Not only that, this task is also considered to be able to train students' mentality, through this task students' discipline and sense of responsibility will slowly grow.

Therefore, the researcher considers that the summary of assignments in the seminar proposal course has a good impact on students, in other words the washback effect on this assignment is positive. This research can contribute to the world of knowledge, especially education because there are many new experiences and learnings gained by educators since learning is done online, educators adapt well so this research 
can help educators to understand the important role of the washback effect, especially in English language assessment. In addition, the society can also be helped by this research because they will understand that today's world is dependent on technological developments that require everyone to be able to use it wisely.

\section{Suggestions}

Following this research, it is suggested that the educational community need to take more initiative in allocating assignments to students during the Covid-19 pandemic. Therefore, in the future, it is hoped that educators who perform a wider variety of tasks will be able to carry out research with the aim of instilling responsibility and discipline for students' education.

\section{REFERENCES}

Alan Jaelani, A. U. (2021). Preparing EFL pre-service teachers for curriculum 2013 through authentic materials and assessment integration. JEES (Jpurnal of English $\begin{array}{lll}\text { Educators } \quad \text { Society), } & 6(1), & 171-177 .\end{array}$ https://jees.umsida.ac.id/index.php/jees/article/download/829/1566

Amalul Umam. (2017). Proficiency Test Design: An Example And Its Analysis. English Journal, 20(1), 1-16. http://150.107.142.43/index.php/ENGLISH/article/view/1510

Dewi, W. A. F. (2020). Dampak COVID-19 terhadap Implementasi Pembelajaran Daring di Sekolah Dasar. EDUKATIF: Jurnal Ilmu Pendidikan, 2(1). https://doi.org/10.31004/edukatif.v2i1.89

Donzelli, G. (2003). Teaching Languages to Young Learners. System, 31(3). https://doi.org/10.1016/s0346-251x(03)00040-x

Gultom, E. (2016). Assessment And Evaluation In Efl Teaching And Learning. Assessment and Evaluation in Efl Teaching and Learning.

Hakim, M. A. R., \& Saputra, A. (2020). Efek Washback Ujian Nasional Subyek Bahasa Inggris Pada Tingkat Sekolah Menengah Pertama (SMP) di Indonesia. Tadbir: $\begin{array}{lllll}\text { Jurnal Studi Manajemen Pendidikan, } & 4(1),\end{array}$ https://doi.org/10.29240/jsmp.v4i1.1273

Kearns, L. (2012). Student Assessment in Online Learning: Challenges and Effective Practices. Jolt.Merlot.Org, 8(3).

Nuriyah, N. (2014). Evaluasi pembelajaran: Sebuah Kajian Teori. Jurnal Edueksos, 3(1), 73-86. https://doi.org/10.1165/rcmb.2013-0411OC 
Poerwanti, E. (2015). Konsep Dasar Asesmen Pembelajaran. Konsep Dasar Asesmen Pembelajaran, 1 .

Saputri, T., Khan, A. K. B. S., \& Kafi, M. A. (2020). Comparison of Online Learning Effectiveness in the Ele During Covid-19 in Malaysia and Indonesia. PIONEER: Journal of Language and Literature, 12(2). https://doi.org/10.36841/pioneer.v12i2.700

Syah, R. H. (2020). Dampak Covid-19 pada Pendidikan di Indonesia: Sekolah, Keterampilan, dan Proses Pembelajaran. SALAM: Jurnal Sosial Dan Budaya SyarI, 7(5). https://doi.org/10.15408/sjsbs.v7i5.15314

Uno, H. B. (2017). Assessment Pembelajaran. In Bumi Aksara.

Wahyuni, S. E., \& Inayati, N. (2020). The Problems of Generating Ideas Faced by English Language Students in Research Proposal Writing. PIONEER: Journal of Language and Literature, 12(2). https://doi.org/10.36841/pioneer.v12i2.633

Washback of Continuous Assessment. (2016). http://eprints.usm.my/31599/1/SAAD_FAHAD_ALDAWOOD_24.pdf

Yunita, N. W. (2020). Penyebab, Asal Mula, dan Pencegahan Virus Corona di Indonesia. In Journal of Environmental Management. 